Vol. 1, nº 1 | 1997

Varia

\title{
A decline in violence in Ireland ? Crime, policing and social relations, 1860-1914
}

Mark Finnane

\section{OpenEdition}

\section{Journals}

Electronic version

URL: http://journals.openedition.org/chs/1031

DOI: $10.4000 /$ chs.1031

ISSN: 1663-4837

\section{Publisher}

Librairie Droz

\section{Printed version}

Date of publication: 1 January 1997

Number of pages: $51-70$

ISSN: 1422-0857

\section{Electronic reference}

Mark Finnane, «A decline in violence in Ireland ? Crime, policing and social relations, 1860-1914»,

Crime, Histoire \& Sociétés / Crime, History \& Societies [Online], Vol. 1, n | 1997, Online since 03 April 2009, connection on 19 April 2019. URL : http://journals.openedition.org/chs/1031 ; DOI : 10.4000/ chs. 1031 


\title{
A decline in violence in Ireland? Crime, policing and social relations, $1860-1914^{1}$
}

\author{
Mark Finnane
}

\section{INTRODUCTION - VIOLENCE IN IRELAND}

Treland, it was said in 1971, even at the outbreak of the Troubles, was a peaceful society, one of the most peaceful in Europe and ranking very low on international league tables of deaths by homicide ${ }^{2}$. In citing Ireland as a 'most favoured country' in a comparison of western crime rates, Ted Robert Gurr in 1979 speculated in passing that 'its relatively low volume of crime may be credited to its Gaelic culture, religious traditionalism, or simply its small urban population ${ }^{3}$. The history of the north, and of increasing crime in Ireland generally since the 1960 s reversed such an image, although clearly it might be repeated that this violence was specific to a particular time, place and political context.

In the meantime the bloodletting has provoked reflection and query. In some recent cultural commentary on Ireland violence emerges as the sore at the heart of a culture which must begin to take it seriously. Two films, based on the work of two of Ireland's best known contemporary writers, expose the costs of unrestrained and little understood violence. In Neil Jordan's Angel the initial, almost accidental, fall into violence of the film's anti-hero precipitates a bloody saga of seemingly uncontainable proportions, with a barely disguised metaphorical message on the politics of violence as a choice in modern Ireland. Roddy Doyle's script for a TV drama series, Family, confronts violence in a different domain. Here, in a thoroughly realist genre, it is a family facing the consequences of domestic violence, a violence which is pervasively documented in physical, mental and sexual abuse of a number of family members by the father. Admittedly, there is a level at which Doyle's writing in this series extends beyond a purely local culture - it is difficult not to imagine it serving as a tale of domestic violence and familial misery in any modern Western country.

If these two powerful stories discourse on a truth about contemporary Ireland, they do no more, nor less, than continue a tradition of social criticism which has been

\footnotetext{
1 Presented at the American Society of Criminology Conference, Boston, November 14-17, 1995. This paper is part of a larger project on the decline of inter-personal violence, 1860-1930, in conjunction with Simon Stevenson of Griffith University, and funded by an Australian Research Committee Large Grant (1995-1997) - see Finnane and Stevenson (1994); and Stevenson (1994).

2 Rose (1971, p. 424-425, 429-430.

3 See Gurr $(1979$, p. 363).
} 
associated with some of the country's most influential artists. James Joyce (of whom Brenda Maddox noted a particular aversion to physical violence) writes in Dubliners of Eveline, whose unsuccessful struggle to leave her stifling family and culture springs in part from her revulsion from the violence of her father ${ }^{4}$. The mundane realities of everyday life in Ireland, represented in these various cultural reflections, seem to encompass a violence which lies just beneath the surface, and is only partly evident in the culture's long tradition of political violence. That is, there is a violence which is noticed but largely evaded by a culture and polity which has been for long preoccupied with only one kind of violence, that associated with political disaffection or dissent. Perhaps there is more than this. Has there even been, as Joseph Lee suggests, a perversion of public moralities which allowed the preoccupation with sex to displace a concern with all other immoralities, such as the "the morality of violence, the morality of perjury, the morality of deceit in commercial and legal transactions's.

This prelude allows me to approach my theme in a particular way, that is as a question about social history which arises not simply out of a very contemporary concern with violence and its control. Rather I suggest that a history of violence in modern Ireland focuses attention on an aspect of the society's history which is already present in its cultural history, but in a way which is constantly subordinated to other themes. Elsewhere I have suggested that an examination of Irish criminal statistics in the second half of the nineteenth century is likely to show a society which was not so exceptional in its development, a society which experienced for example, a general decline in levels of violence after the middle of the nineteenth century, like many others in the western world at the same time ${ }^{6}$.

Such a historical experience was at odds with a widespread public perception of Ireland in the later nineteenth century as a country characterised by high levels of violence. The focus of policy attention was above all on the manifestations of violent resistance to the fundamental social order of a rural society in which disputes over the ownership and use of land were endemic, though no more so it has been argued than was characteristic of 'pre-modern' societies. Perhaps, Townshend suggests, the 'pre-modern' context was even relevant to understanding some of the elements of violence in Belfast in the later nineteenth century as survivals of carnivalesque release ${ }^{7}$. The tendency of the British government to rule Ireland by coercive measures through much of the century reflected the alarm at levels of violence which, whatever their roots in more localised social relations ${ }^{8}$, were taken to be evidence of a society in a state of anarchy. All the same, even in the context of conditions most conducive to political violence there appeared by the 1880 s to be some striking evidence of the decline of 'crude personal violence' as an agrarian mode of assault on the landlord system. ${ }^{9}$ If this was the case it appears to be of a kind with

\footnotetext{
Maddox (1988); see 'Eveline' in Dubliners (Levin, 1963, p. 374-375).

Lee (1989, p. 645).

See Finnane (forthcoming). See also Vaughan (1994), p. 140, 163.

Townshend (1983, p. 45-48). The relevance of modemization to understanding the extent of violence in peasant Ireland is emphasised in the Conclusion to Clark and Donnelly (1983).

8 A dimension explored especially by Fitzpatrick $(1982,1985)$.

9 Townshend (1983, p. 150).
} 
other evidence discussed below which suggests a decline in other incidents of personal violence.

Such an observation was hinted at in official comment even in the midst of the worst outbreak of violence in the early $1880 \mathrm{~s}$. W. Neilson Hancock, the skilled and observant statistician whose reports on the judicial and criminal statistics spanned the years 1863-1881, noted in his last report that

while the country has been shocked by some fearful crimes it affords hope in applying remedies to find that minor offences have on a large scale been successfully diminished at the very time that serious crime was increasing ${ }^{10}$.

Hancock's predilection was for social explanations of the major shifts in crime, a phenomenon he considered sensitive to economic pressures and social provisions. One had to go back to 1864 , he explained, to see a figure comparable to the serious crime rate of 1881 - and that had also been a year in which Ireland's rural economy had been placed under enormous pressure. The capacity of the nineteenth century state to address some of the causes of crime was elliptically addressed in Hancock's reference to even earlier crime waves in times when social organisation was very different: 'In 1846 the Poor Law was not so adequate, before 1838 there was no Poor Law, before 1835 there was a tithe question, and before 1830 less efficient police' ${ }^{11}$. The almost academic detachment of these observations at such a time were not however a symptom of the general governmental response to yet another outbreak of Irish crime - and in the 1880s the British government in Ireland again pursued coercion in a desparate attempt to bring the country back under control. The study of violence in Ireland must necessarily steer a careful course through a mass of data which threatens attempts to discover a secular trend running through the rises and falls of political disturbance.

In order to advance the study of this subject beyond the impressionistic stage of most existing research this article examines some of the official data about crimes of violence in the post-Famine period. It further explores the geographical and gender variations of this evidence, to raise some issues about differences within a culture. Finally it considers what kinds of evidence or data could help us to explain the patterns described. The violence involved is primarily that which came to the notice of the public authorities, especially the police and the coroners. The relevance of other forms of violence cannot be disputed - and it may also be that it is in reference to changing attitudes to the modes of behaviour which lay outside the domain of violence that we may discover the best clues to the changing patterns we are able to discern in the criminal statistics.

\section{A DECLINE IN VIOLENCE?}

As an index of violence, evidence of homicide warrants prior attention. Criminologists and crime historians incline to the view that homicide statistics are

10 Criminal and Judicial Statistics 1881, Ireland, p. 16, British Parliamentary Papers, 1882.

11

Ibid., p. 15. 
harder than other crime data - but even so there are different sources for the evidence of homicide in the past. Two kinds of data - police interventions and coronial inquiries - yield evidence for the period covered by this study. Graph 1 compares the record of both police arrests and the results of inquests into the cause of violent death, by grouping murder and manslaughter. While there are annual fluctuations across the period there is a marked falling off from the early $1890 \mathrm{~s}$. This followed what was undoubtedly one of the century's most violent decades, that of the $1880 \mathrm{~s}$, with peaks in $1880,1882,1887$ and then finally 1891 . The reasons for the peaks are not difficult to seek - they were clearly linked to the agrarian and political agitations of these decades. But beyond this it is evident that the other story of the statistics of violent death is that Ireland in the Edwardian period was very much a more peaceable society than Ireland of the mid-Victorian era. The evidence of both inquests and of police arrests trends in the same direction.

Graph 7: Homicide, Ireland 1864-1914

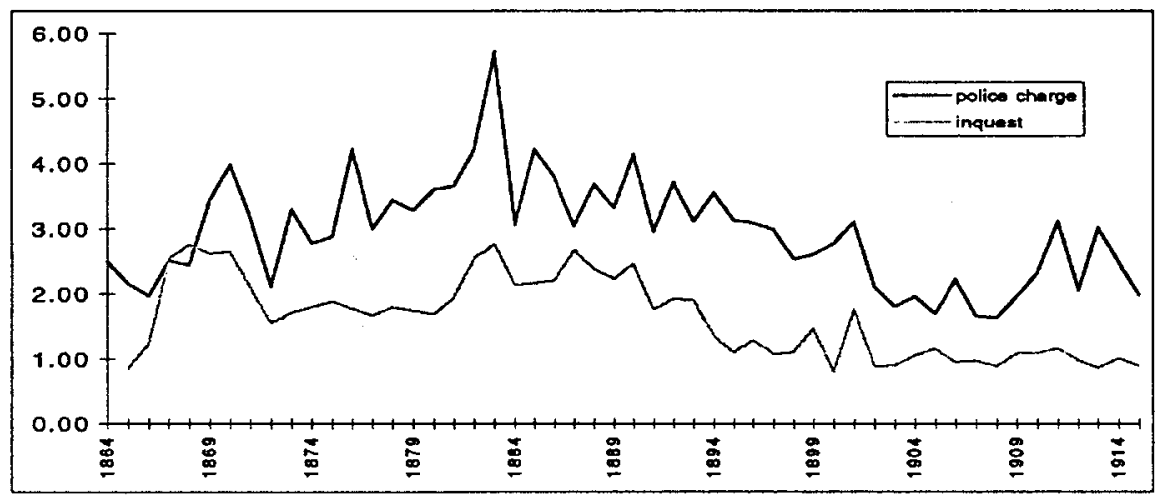

Source: Judicial Statistics (Ireland) for police arrest and charge; Registrar-General 's Annual Reports (Ireland), for cause of death at inquest. Incidents per million population.

Across the half-century from 1864 then, the picture of homicidal violence is one of secular decline, as it was for many other societies at this time ${ }^{12}$. Such an index might point to a more general decline in inter-personal violence. In fact when we look at comparative data from non-homicidal violence there is some strong evidence of a more general decline. The point is tellingly illustrated if we construct indices of police charges of homicide and compare those of serious assault, as in the accompanying graph. It is clear on the basis of this view of the official data that there was a very marked decline in the prosecution of indictable common assault prior to the 1880s.

But was this decline one which occurred only in more serious cases of assault? A comparison of persons tried on assault in the summary courts with those tried before a jury suggests even more strikingly that there was a long term decline in

12 See Monkkonen (1994, p. 201-203) for a recent summary of comparative evidence. There remain contradictory examples however. Howard Zehr's earlier study of crime and modernization in Germany and France which argued for a decline in violence in the course of industrialisation during the nineteenth century has recently been questioned by Eric $A$. Johnson's more detailed examination of the German data (1995, esp. ch.3). 
Graph 2: Violence in Ireland: polices charges 1863-1914.

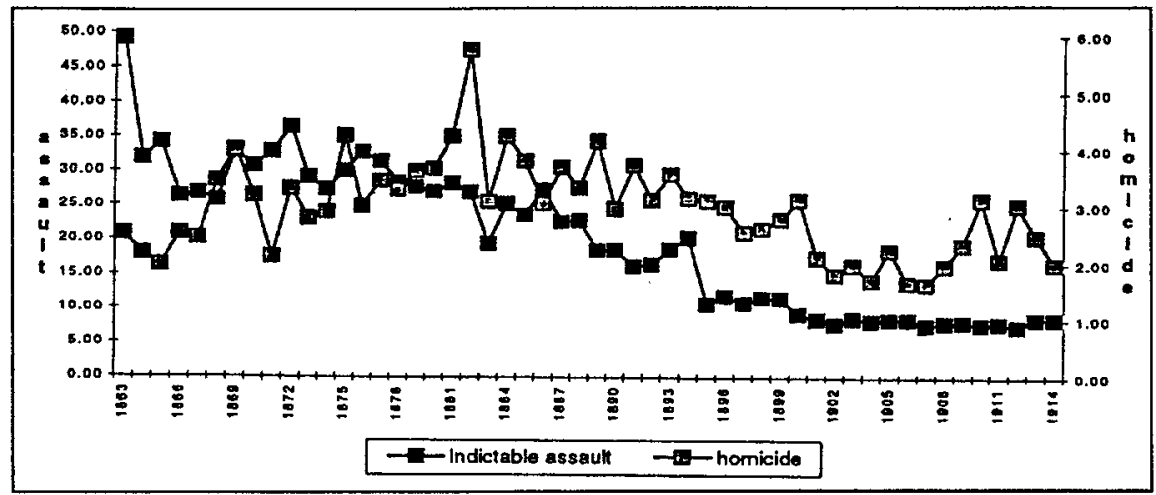

Source: Judicial Statistics, Ireland - police arrest and charge (as for all statistics in this paper unless otherwise indicated). Indictable assault includes shooting, common assault, assauit on peace officer (indictable) and grievous bodily harm; homicide includes murder, child murder and manslaughter. Incidents per million population.

the incidence of prosecution of assault of most kinds in the three decades leading to the first world war. I caution 'most kinds' because more detailed scrutiny of some categories will suggest a more complex picture.

In sum the preliminary evidence from the source (police arrests) which, in the absence of victim surveys, is regarded as most probably reflecting an incidence of certain kinds of social behaviour confirms a pattern which is recognisable in other jurisdictions. Throughout the later nineteenth century and down to the First World War there was a notable decline in the police prosecution of violent assaults of both a fatal and non-fatal kind. This was true also of the summary charge of common assault which may be read in some ways as an indicator of a disposition to deal interpersonally in a way which is marked by conflict, antagonism, or simply with a degree of aggravation. When we take another index, that of coronial inquiries into violent death, the evidence seems further confirmed. These are noteworthy observa-

Graph 3: Assault in Ireland, 1863-1914.

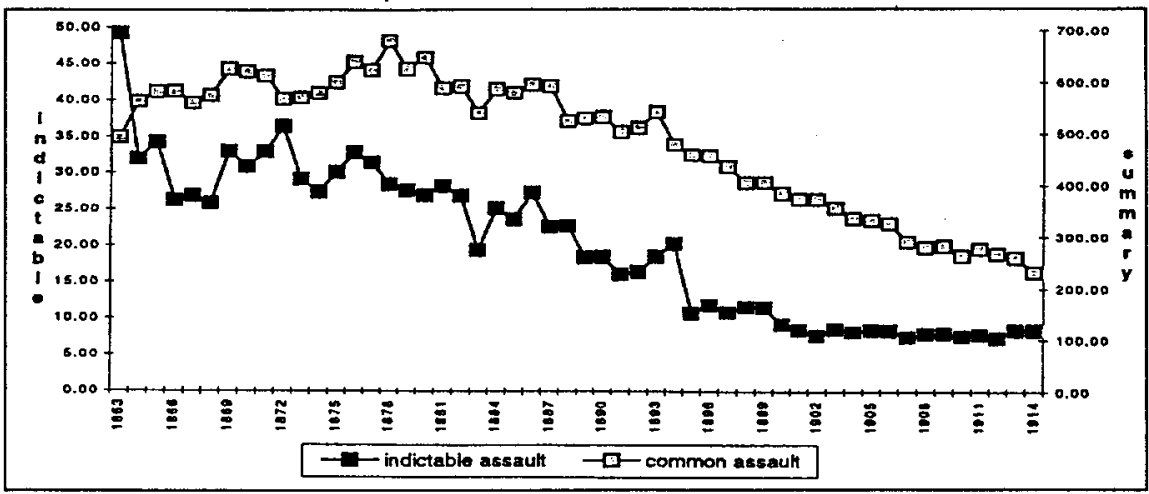

Source: Judicial Statistics, Ireland; indictable assault includes charges as in previous graph; common assault is summary charges of common assault. Incidents per million population. 
tions of a society which was regarded by many observers for most of the long period of the Union down to 1921 as ungovernable.

Before exploring some data which might contribute to explaining these trends, it is worth noting that more detailed analysis of the homicide data, especially of its sex-differentiations, raises further matters for exploration. The coronial inquest data makes possible a differentiation by age and sex of the victims of alleged homicide. The data suggests, interestingly, a convergence of the numbers of male and female victims by the early 1900s. The crucial data which allows us to interpret this is age at death. Although I have not analysed this in detail yet, the data from the 1870s shows that most of the female cases were infanticide victims, with many fewer adult victims than was the case for males. If such a trend continued by the early 1900 s what we would be looking at in this comparative data is the outcome of a process where infanticide was still relatively common.

The data on sex of offender (Graph 5) charged with homicide conforms with this data on victims, as there is a convergence between numbers of males and females charged by the 1900 s (possibly replicating an earlier pattern before the 1870 s). A greater readiness to prosecute infanticide where it was discovered would help explain such an outcome.

Graph 4: Homicide victims - inquests, Ireland, 1864-1914.

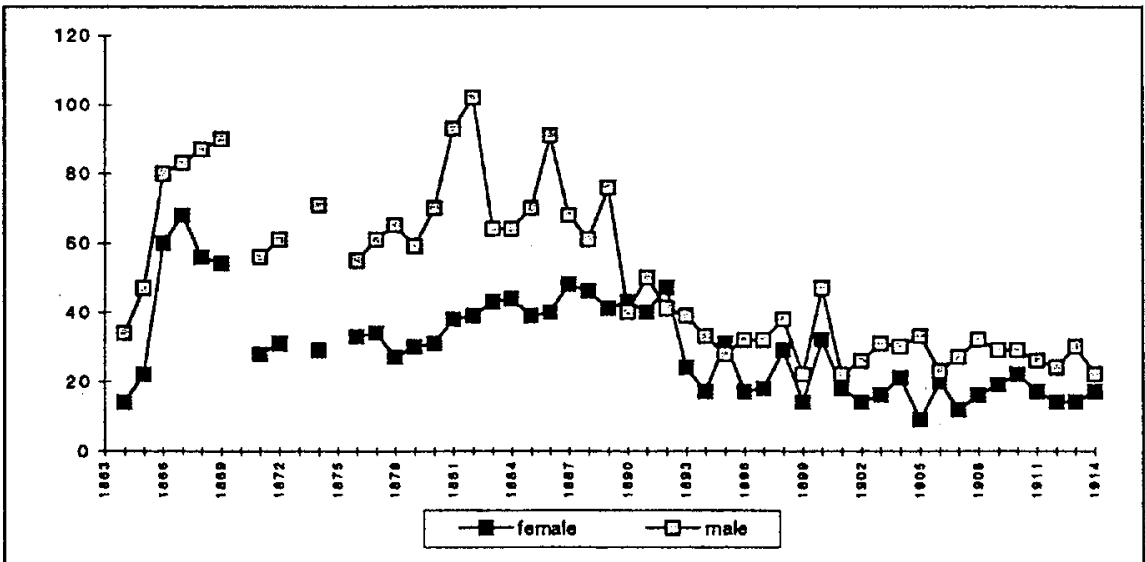

Source: Causes of Death, Annual Report of Registrar. General. Number of females/males who where victims of homicide, as found by coroner.

\section{POLICING A DECLINE IN VIOLENCE?}

How important was policing to the changing pattern of violence prosecution? In a striking phrase, Gatrell has characterised the later nineteenth century Victorian state in England as a 'policeman state'. That phrase conveys Gatrell's view that the 
Graph 5: Charges of murder, Ireland, 1863-1914.

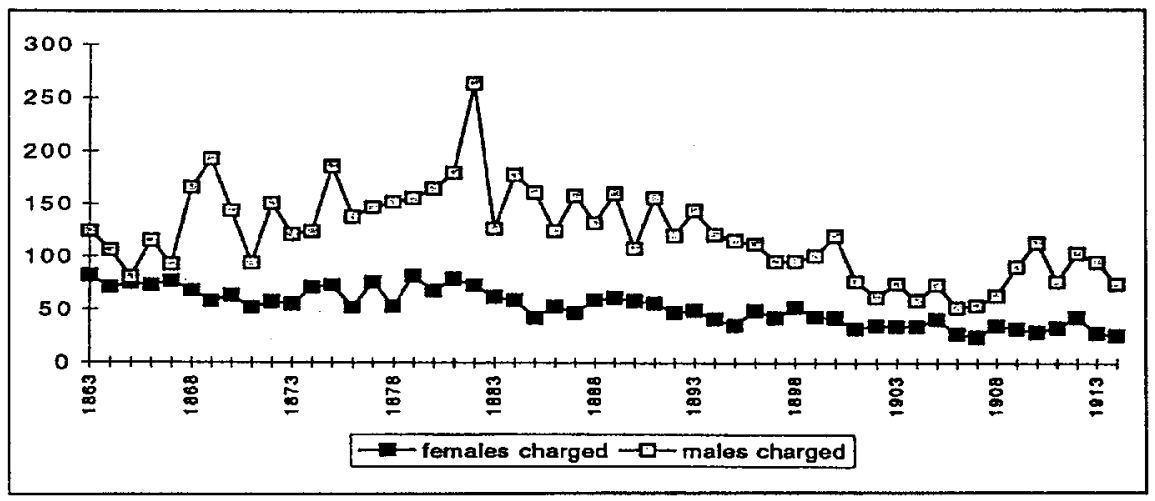

Source: Judicial Statistics, Ireland - number of persons charged, including murder, manslaughter and infanticide

police played a significant role in the organisation of social life, fostering conditions of good order (if not of social equality). Gatrell's earlier work on patterns of prosecution of crime in Victorian and Edwardian England had already pointed to the significance of a decline in prosecutions as an indicator of changing patterns of social relations in which the role of police as social control agents had a productive effect ${ }^{13}$.

While a great deal more work is required before we can extend such judgments to Ireland (and even test them adequately in England), there is some point in considering just one piece of statistical evidence which we might regard as consistent with a productive role of police in effecting some change in the rates of public violent offending in the later nineteenth century in Ireland. The ratio of police to population was certainly not declining in the six decades before the First World War. While there were fluctuations in this ratio, the figure at turn of century was still higher than it had been before the 1880 s and remained higher than the pre-1880 level to the outbreak of war in 1914. In spite of some decline in total indictable prosecutions, police numbers were maintained at a time of declining population. Comparing the number of offences per police officer gives us some sense of how active or otherwise the police were. What the graph below suggests is that police, whose numbers were at high ratios relative to earlier in the century, continued to be active in pressing both indictable and summary charges, even at the same time as the society was becoming noticeably less violent.

Further scrutiny suggests that, in Ireland as elsewhere, much of this continued activity was of focussed on street cleaning activities, the prosecution of drunkenness being an obvious and influential factor in police work. The implications of these observations for the effect of policing on violence are quite indirect. It would take a larger leap of faith than could be justified to presume that police played the crucial role. Barring a very intensive saturation of the society with guardians of law and 
Graph 6: Number of offences per police officer, Ireland, 1864-1913.

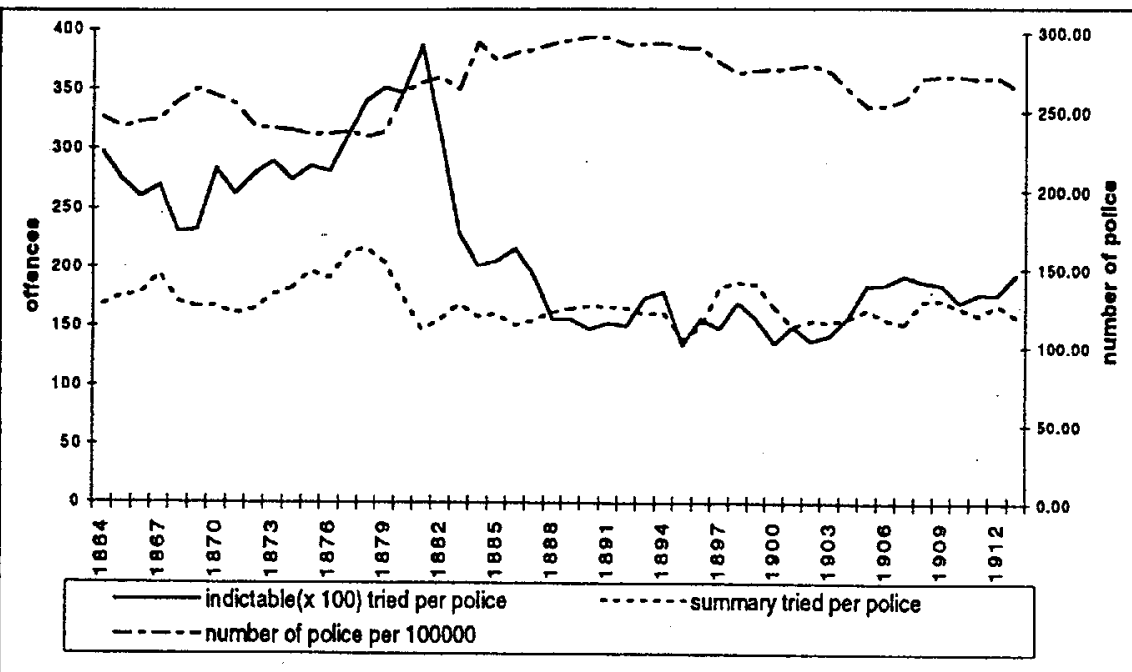

Source: Judicial Statistics, Ireland. The data is derived from the summary tables (of cases tried in assizes, quarter sessions and sumnary courts), published from 1895, with annual reports of comparable data for the period before 1876 . The measure is of cases which were brought to court, not of those arrested, as with most of the other data in this paper.

order, the capacity of police to exert a constant watching brief over public behaviour has been consistently questioned by empirical research.

What other research has also demonstrated however is the importance of police discretion in prosecution and the consequent sensitivity of policing statistics to changing priorities of police, whether or not these are directed by other environmental factors. By examining in greater detail the range of charges preferred against offenders in the domain of offences against the person we can start to qualify the conclusions we might draw from the gross figures of indictable and summary charges involving offences against the person, as discussed earlier. In the following discussion I scrutinise in some detail the trends of data on policing of a number of categories of offence which might be theorised as relating to changes in social behaviour bearing on the incidence of violence. The offences examined below include various sub-categories of assault, of attempted suicide, of rape and attempts, and of cruelty to animals, the last an offence which might bear an interesting relation to changing modes of personal behaviour and social norms.

\section{ASSAULTS}

Within the category of prosecuted violence there were of course numerous kinds of behaviour and legal definition. It is possible that changes in definition of offence were occurring which made the appearance of declining prosecution a chimera. There is some evidence for example that certain kinds of offence which brought prosecution during these six decades defied the trend of decline. A notable instance is 
the charge of aggravated assault. This charge, legislated in 1861 as a provision under which justices might award a harsher punishment for assault and battery of women and children, was the subject of increasing numbers of prosecution up to 1900.

Graph 7: Aggravated assault, Ireland, 1863-1914.

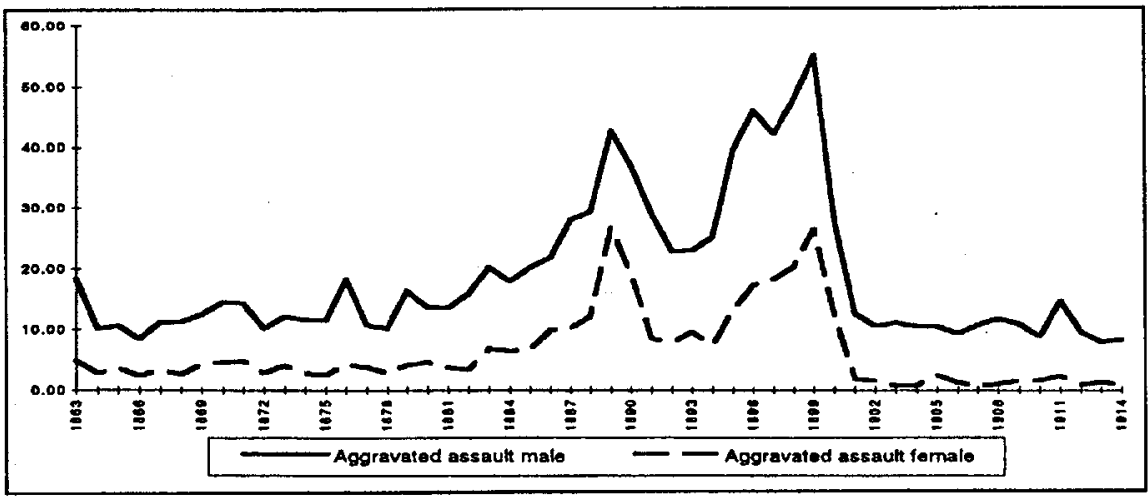

Source: Judicial Statistics, Ireland. Male and female offenders charged, per million.

As the table indicates it may be that a change in recording procedure after that date makes the subsequent history of this offence difficult to judge. But the accelerating numbers of arrests through the 1880s and 1890s, for both male and female offenders, suggests a changing attention to a category of violence which was the object of contending interests in the nineteenth century ${ }^{14}$.

The increase in charges of aggravated assault up to 1900 is capable of various interpretations. One may be the greater confidence or willingness of women to press charges of this kind - one of the few assault charges which became the subject of judicial interpretation involved just this offence, when in 1872 Isabela Rice charged Thomas Rice after he threatened her with a rifle and otherwise assaulted her $^{15}$. Another instance making it to the law reports involved the daughter (of unstated age) of John Clarke of Aughnacloy, Co Tyrone, who had assaulted her in an attempt to get her to return home as, it was said in the appeal, 'she had been giving himself and his wife a great deal of trouble in staying away from home ${ }^{16}$.

An alternative, and of course not exclusive, interpretation is that police and magistrates were somewhat more willing to prosecute such cases by the late nineteenth century. Such an explanation presumes a policy direction; or else a change in sensibility about domestic violence and the unacceptability of physical abuse of

14 Conley (1991, p. 74-75) commenting on the situation in England. In a recent article on women and violence in Ireland, Conley has presented much evidence suggesting a more sympathetic attitude on the part of the Irish judiciary (as compared with England) to women as offenders and victims, though her article covers mainly indictable crime and does not address charges of aggravated assault: see Conley (1995).

Is In re Rice, (1873-1874) Ir. Reports, VII, 74.

16 Ex parte Clarke, (1890-1891) ILR, XXVI, 3. 
women and children. The latter might be presumed to be the stronger explanation since, on matters of policy, police were being explicitly instructed in nineteenth century police manuals to avoid too close an interference in domestic disputes. But there is another factor in this category of assault which requires more attention. The unpredictably high number of female defendants on this charge does suggest a readiness of police to intervene in circumstances which require detailed archival inquiry. Moreover this was a charge whose incidence, like so much in the Irish context, reflected the intensity of policing in the country's largest urban centre, Dublin. The graph below shows the much greater incidence of the charge in Dublin as compared even with Belfast, while a sample of almost any other region of Ireland would reflect much the same relatively low incidence as does our example of Galway.

Graph 8: Aggravated assault, Ireland and selected regions, 1863-1914.

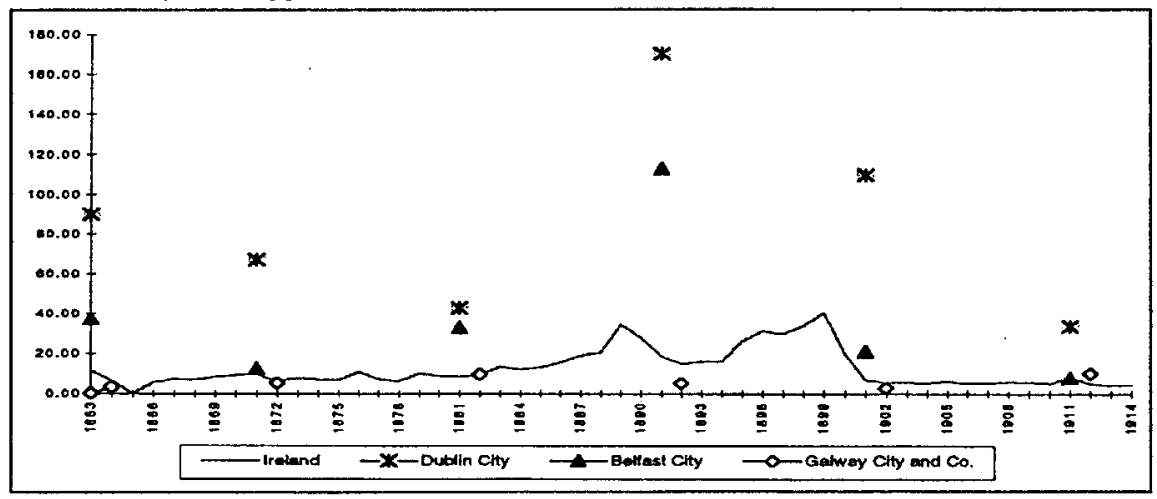

Source: Judicial Statistics, Ireland - data for regions is three year average (eg at 1871, represents 1870-2).

Another category of assault which is commonly seen as related to the question of consent to policing is that of assault on police. Arrest on such a summary charge includes occasions of resisting or obstructing police in the course of their duty: since the burden of proof is effectively placed on the defendant to show that they did not assault police, in a context where the court is typically inclined to accept the word of police, the charge is an important index of police readiness to assert their authority. The extent to which such a charge carried with it a very high chance of conviction in the summary courts is indicated by comparing conviction rates for assault police and other assault categories, as in the following graph.

The evidence is consistent across four decades of data, that a charge of assault against police was almost invariably followed by conviction, making the charge one which police could deploy in confidence of being backed by magistrates. The incidence of assaults against police might therefore be seen as reflecting an incidence of tension between police and the policed.

If so then the following evidence of the incidence of charges suggests again an increasingly peaceable society.

The sheer volume of this charge (running to thousands of cases each year) together with the high correlation of the pattern of charging of males and females 
Graph 9: Conviction rates, assault charges, Ireland.

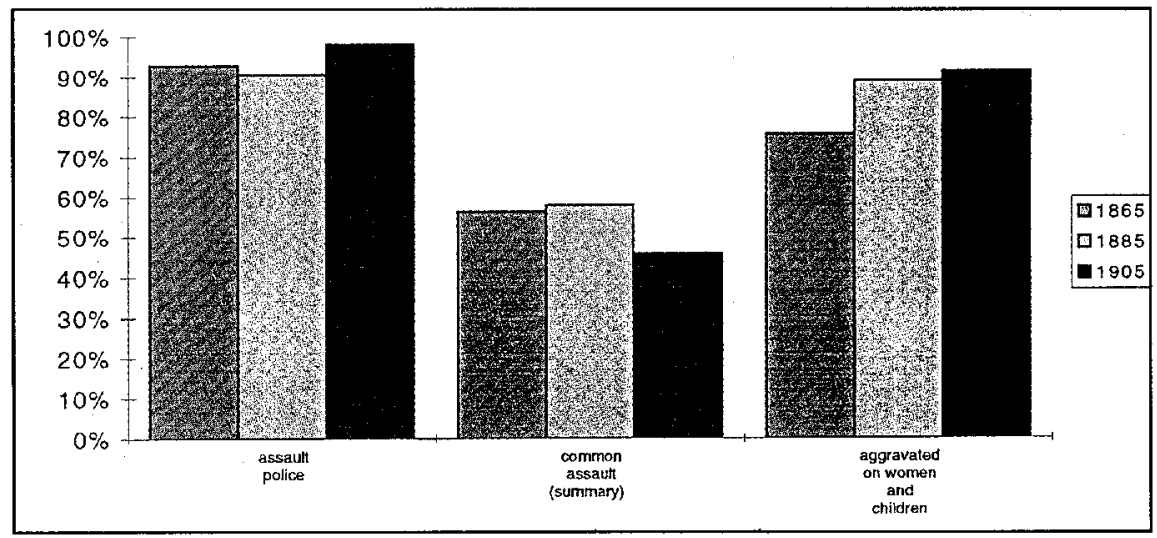

Source: Judicial Statistics, lreland

Graph 10: Assault on police (summary charge), Ireland, 1863-1914.

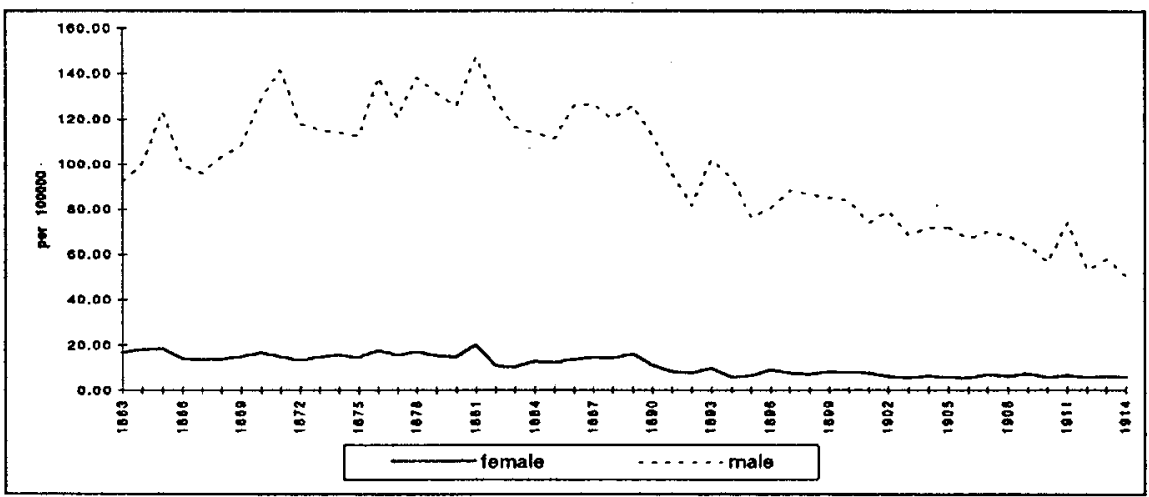

Source: Judicial Statistics, Ireland

$\left(\mathrm{R}^{2}=0.86\right)$ might be seen as providing convincing evidence of a police disposition of an increasingly quietist kind, one which might be consistent with a lessening of public, street-based conflict. Consistent with such a long-term change in policing dispositions is the argument of Lowe and Malcolm that the constabulary in Ireland was itself 'domesticated' in the later decades of the nineteenth century, being increasingly disarmed, and more a part of local communities, being used as they comment more as an agent of 'house-keeping' than of 'peace-keeping' ${ }^{17}$.

A pertinent issue in this regard is the intensity of patterns of policing in urban versus rural areas, as well as the varieties of conflict within those areas. As with so much of the evidence of policing in Ireland in these decades the incidence of charges shows significant difference between different areas of the country. This is notably

17 Lowe and Malcolm (1992). 
the case with assaults on police, which in Dublin in the early 1860 s are recorded at 5 times the rate in the closest other county or urban area. Viewed against other evidence of assault (ie summary common assault) this is a striking differential, since there was nothing exceptional about the rate of charges of common assault in Dublin at this time.

This record of Dubliners' conflict with police evidently continued as the accompanying graph shows in relation to evidence from 1911. However by this time the Dublin experience was much less exceptional, with two rural counties exceeding the Dublin rate of charges of assault on police, and Belfast exhibiting much the same pattern as Dublin.

The complexity of the changing incidence of such charges suggests yet again the importance of a more detailed scrutiny of the available policing, court and newspaper records which will have to be the subject of further study. Other researchers however have noted the marked hostility between the police and people in both Dublin and Belfast. On the basis of a survey of press reports of assaults on police in Dublin from the 1830s to 1914 Brian Griffin concludes that there was nothing less than a 'long-running feud between the Dublin Metropolitan Police (which was a unique force in Ireland in any case) and the city's 'lower classes' ${ }^{18}$. The ferocity of sectarian dispute and labour troubles in Belfast from the 1880s also did little to improve the tempers on either side of the policing divide there ${ }^{19}$. If there was a domestication of policing relations as well as of police themselves in Ireland in this period its limits appear to have been reached in the conditions of urban life in the country's two major cities.

\section{SUICIDE AND OTHER 'VIOLENT' DEATH}

For a study which is concerned to understand the relation between the policing of crime and violence on the one hand, and the social conditions of violent acts on the other, evidence relating to incidence of suicide and other violent death is indispensable. Roger Lane's study of violent death in Philadelphia focussed attention on the relevance of suicide and accidental death, but few have followed this lead in later studies of the incidence of violence which tend to focus on the evidence from the policing of murder and manslaughter ${ }^{20}$.

In spite of a century and more of serious social science attention to the phenomena of suicide there has been very little study of it in Irish social history. The following discussion largely replicates the evidence of the only statistical study to date, published by Dermot Walsh in $1977^{21}$. Walsh showed a steady increase in the recording of suicide verdicts in the reports of the Registrar General throughout the later

18 Griffin (1991, p. 793 and ch. ix passim). See also Bridgeman (1993, p. 256) on the excessive levels of assault in Dublin.

19 Griffin (1991, p. 697-706).

20 Lane (1979).

21 Walsh (1976). 


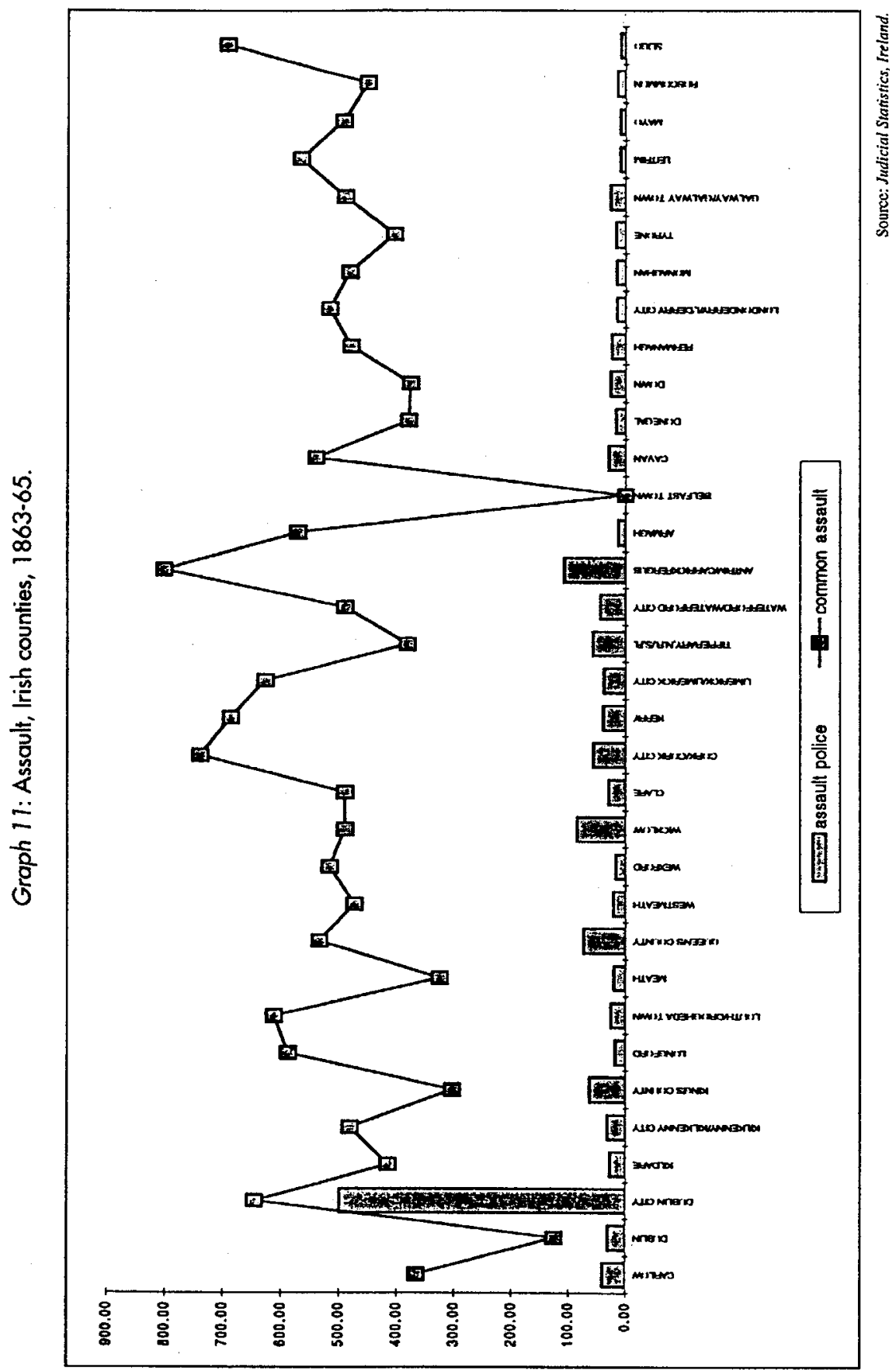


Graph 12: Assault, Irish counties, 1910-12.

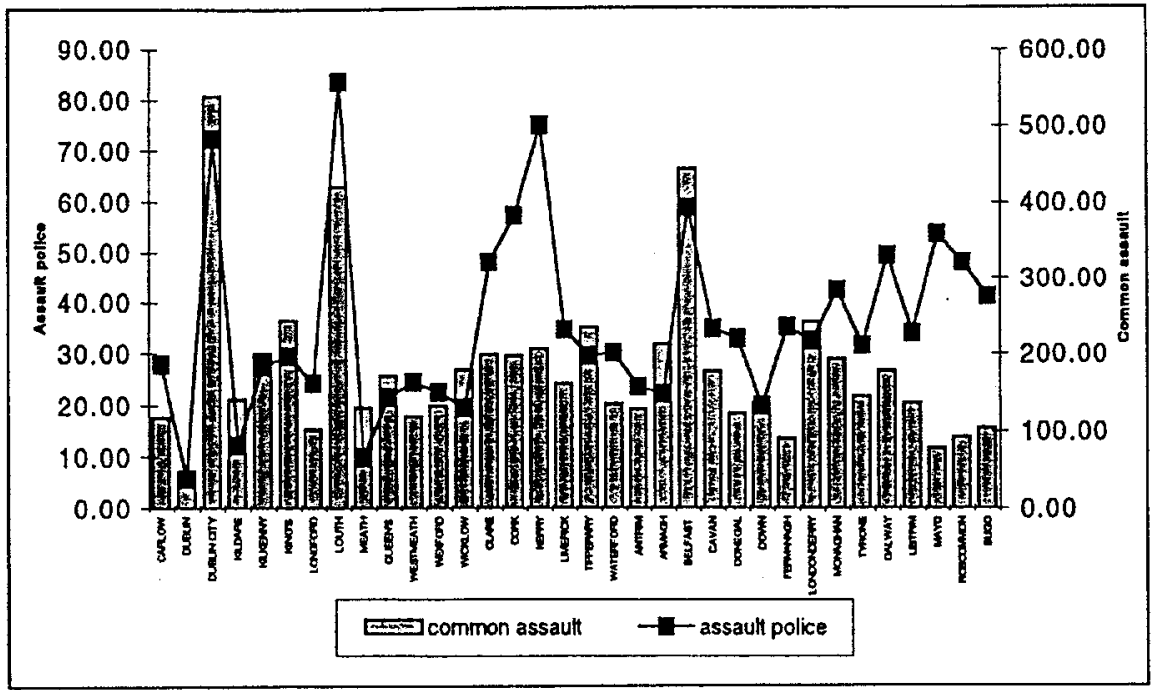

Source: Judicial Statistics, Ireland

nineteenth and into the twentieth century. Comparing such data with the record of admissions to lunatic asylums during the same period gives us a partial picture of what the Victorians called the moral state of the society ${ }^{22}$. Adding to this the data we have discussed above on the decline of assault and homicide produces a highly suggestive contrast, though one not unique to Ireland ${ }^{23}$.

It appears from this comparison that as incidents of inter-personal violence declined there was a simultaneous increase in violent acts against the self, as well as disorders in social relations and personal disposition leading to asylum admission. The question of a relation between these three measures of social action is one for further study in this social history.

Another kind of value attaches to the study of suicide as an index of certain kinds of violence. This arises from the possible implications flowing from the comparison of the coronial verdicts on suicide with the evidence of policing of the offence of attempted suicide. Adjustment of the reported data in the Judicial Statistics to take account of the most likely features of the pre-1895 trend suggests a long term decline in the incidence of police arrest for the offence ${ }^{24}$. The obvious question is

22 Dawson (1911) is one of the rare and interesting contemporary attempts to provide such an analysis of the condition of Ireland.

23 E.g. Lane (1979) for a discussion of these contrasts in externalised and internalised violence especially in relation to race and class.

24 In the graph the data before 1895 has been adjusted to take account of an apparent change in the reporting of official data at that date to include all charges of attempted suicide regardless of their disposition. Prior to 1895 it appears that the Judicial Statistics include only those arrests which police processed through to indictable stage, about one fifth of all arrests for the offence if we take 
Graph 13: Suicide in Ireland, 1866-1912.

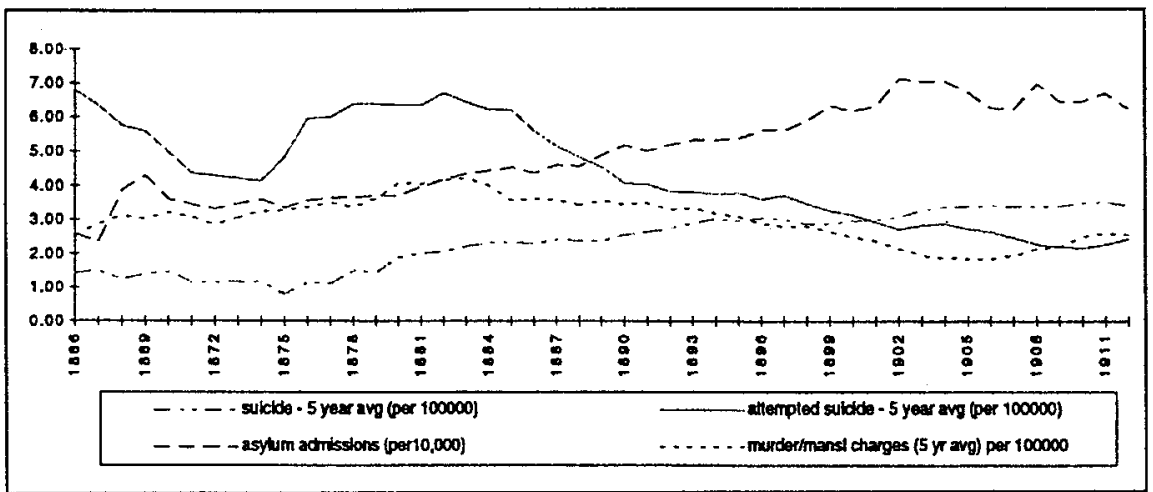

Note: 'Autempted suicide' tracks police charges of the indictabie offence of atterapted suicide (see discussion in fn, 24 for the calculation of this rate); sources include Registrar-General Reports, Judicial Statistics, and data from Finnane, 1981.

whether this also reflected a decline in the incidence of unsuccessful attempts, an unlikely explanation but one which we could perhaps test by noting any other evidence we have about accidental death, some of which might have also included suicide attempts.

Graph 14: Violent death in Ireland, 1864-1914.

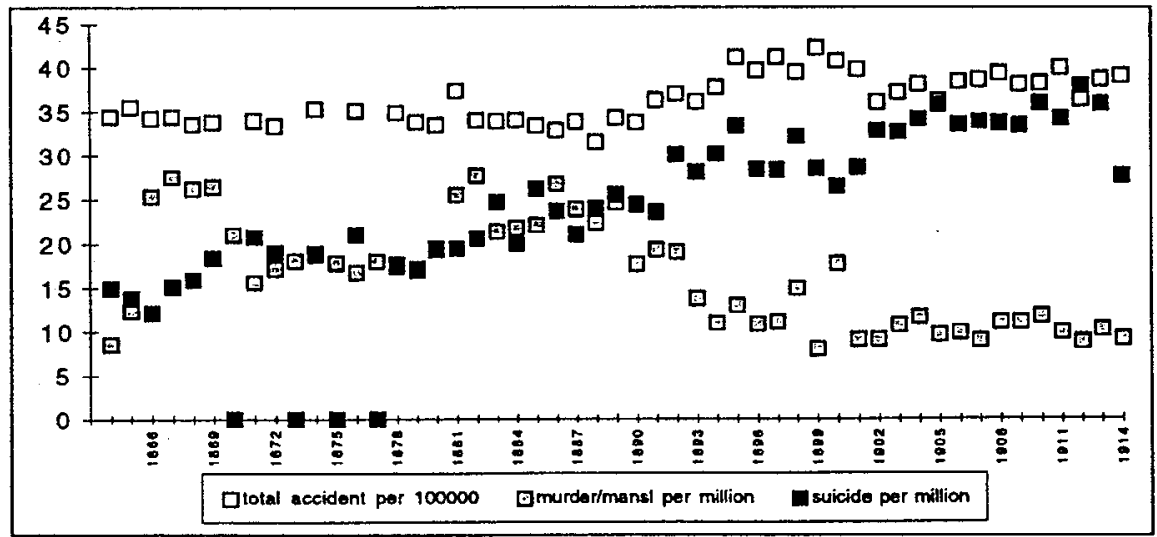

Source: Registrar-General's Reports. Note: missing data for $1870,1873,1857,1877$ for total accident and suicide; values for murder for these years are average of the two adjacent years.

As it happens the evidence suggests a trend upwards in total accidental death especially from the 1890 s, as with suicide. But the breakdown of cause of death in the Registrar-General's Reports suggests that there were differential trends within this total: drowning (conventionally the cause of death most readily contributing to

the data for 1895-6 as a guide. Cf. Anderson (1987, p. 299) who comments on the high rate of use of summary procedure to resolve the charge in London. 
an underestimate of suicide deaths) ${ }^{25}$ trending down, while fractures trended upwards (for the period of recorded data) as did burns and scalds (a category in which women consistently recorded higher rates of death than men). While the figures for drowning prompt a note of caution, it seems unlikely on the whole that there was a secular decline in total number of incidents of attempted suicide, when the completed suicide as well as the total accident rate trended upwards. Accordingly it might be suggested that other reasons to do with policing priorities or practices may be implicated in a decreasing incidence of arrest for attempted suicide. Notably as the asylum became an institution of ready resort and easy access from the 1860 s the tendency to direct attempted suicides straight to the asylum may have contributed to this changing incidence in the policing figures ${ }^{26}$.

\section{RAPE AND ATTEMPTS}

There has been little research on the history of rape in Ireland - a recent extensive bibliography in the special 1995 issue of Journal of Women's History on 'Irish Women' contains no item appearing to deal with the subject historically. More recently however the most substantial research to date touching on the subject has concluded that 'sexual assaults were relatively rarely reported in Ireland', but that they were dealt with more severely than in England. The author of this study, Carolyn Conley, avoids using the official statistics in favour of the more specific detail of the 'Outrage Reports' of the Royal Irish Constabulary, giving her a much finer grained source of evidence than the Judicial Statistics, but one which perhaps underestimates the incidence of police charges ${ }^{27}$. In the absence of systematic comparison of the two sources the conclusions we might draw about the significance of the policing statistics are but a starting point. In terms of our general concern here, however, that of seeking to identify the components of a general decline in the policing and perhaps incidence of violence in the later nineteenth century, the comparative data below is of some interest.

Combining the recorded data of police arrests for rape and attempted rape and comparing this with the general trend for the count of indictable assault indicates that the policing of rape by no means showed a general decline. Rather it displayed fluctuations over a longer time period with some decline only in the early 1880 s and in the first decade of this century, though this was reversed by the end of the period, resulting overall in a constant rate across the period. The relevance of such evidence to the types and incidence of violence will require detailed attention - the impact of policing priorities as well as the interactions of police arrest with the subsequent fate of these charges in the courts are likely to tell us a good deal more about the specific features of this offence and its relation to gender violence during this era.

\footnotetext{
25 Anderson (1987, p. 43-44).

26 Finnane (1981, p. 151-155); Anderson (1987, p. 387-388).

27 Conley (1995, p. 811) reports an average of 74 sexual assault charges per annum between 1865 and 1892. Sexual assault is not defined but appears to cover rape alone, which the figures in the Judicial Statistics suggest covered less than half of all prosecutions for sexual assault in these years.
} 
Graph 15: Rape and indictable assault, Ireland, 1865-1912.

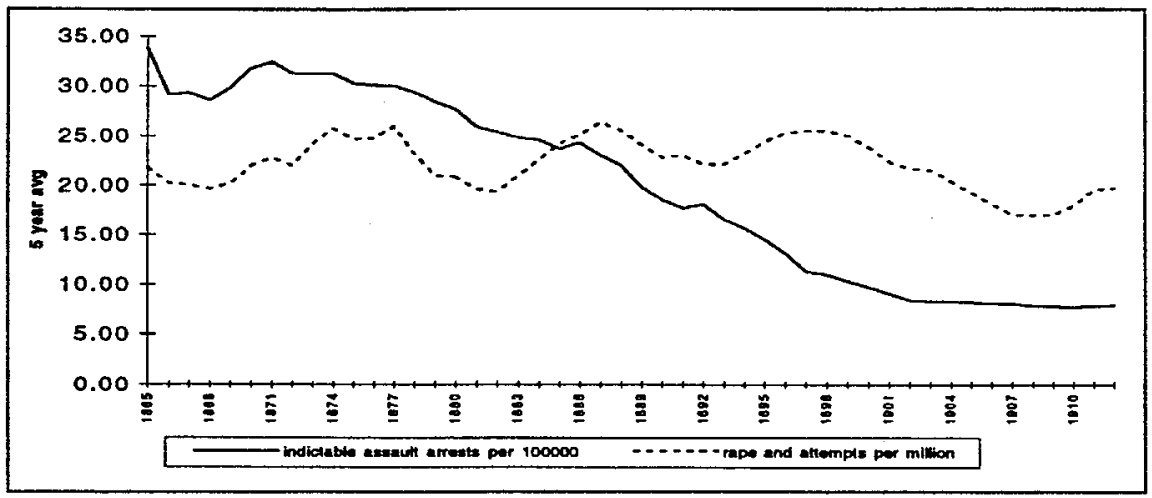

Source: Judicial Statistics, Ireland. The data has been smoothed by a 5 year moving average.

\section{CRUELTY TO ANIMALS}

Finally it seems relevant to take some notice of data relating to a change in nineteenth century attitudes to abusive behaviour more generally, not just in relation to other persons. The summary offence of cruelty to animals was a statutory one in Ireland, legislated in a number of acts from 1849. As a comparison of police charges against both male and female defendants shows, although the rate of charging was about ten males to one female, the rise across the period was consistent for both sexes $\left(R^{2}=0.94\right)$. This suggests a very strong trend in policing of a behaviour which is perhaps less likely to have increased in real terms than to have become more and more the object of surveillance and intervention.

Preliminary comparison of the regional rates suggests that the great bulk of these cases were urban in origin as might be expected. As an index of the capacity of the nineteenth century state to moralise the population at large the significance of this trend in prosecutions leaves us to speculate on the long term effects of such interventions as a mode of reforming popular conduct, as much as a reflection of changing sensibilities.

\section{SUMMARY}

In the light of the data about the policing of sub-categories of violence we have to develop a rather more sophisticated set of questions for historical inquiry. What seems unambiguously to be evidence of a significant decline of violence in Ireland during this period looks on closer examination to be the distillation of a multitude of different trends in data. There seems little doubt that there was a decline in fatal violence of an inter-personal kind - but not of violence directed against the self which showed a strong increase in completed suicide during the half century after 1860 . The policing of violent inter-personal acts showed some striking variation during these years - with evidence of significant interventions around the category of 'aggravated assault', and a relatively constant trend in the policing of rape and 
Graph 16:Cruelty to animals, Ireland, 1863-1914

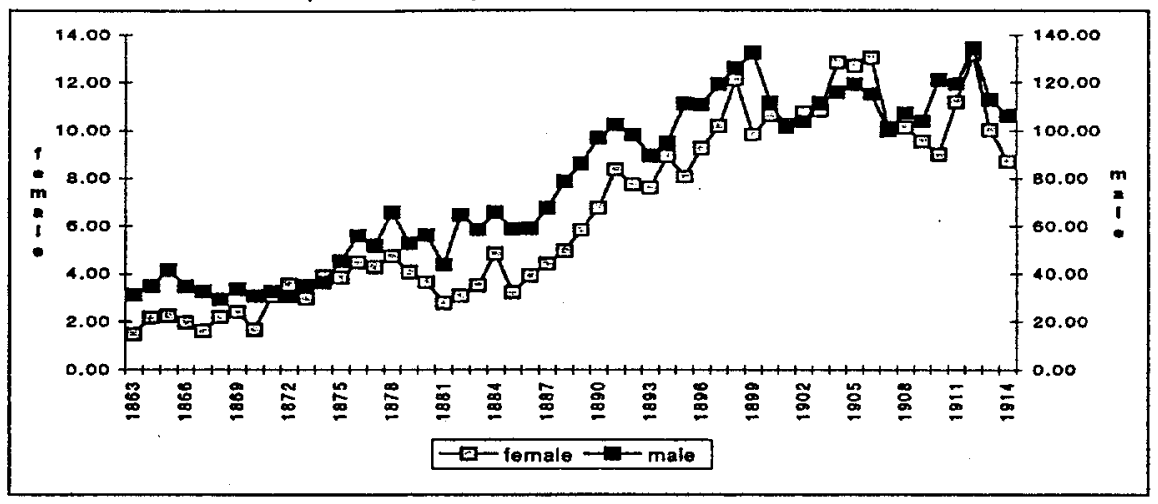

Source: Judicial Statistics. Data is rates per 100,000 population, of police charges in the summary courts.

attempted sexual violence. The vigilant state, probably acting in response to the prompting of non-state agencies, showed in the increasing prosecution of offences of cruelty against animals that its police were not simply retiring to the barracks during these decades of mostly increasing peaceableness in public order. Of particular interest in some of the data which has been analysed is the consistency of measurement of sex-specific arrests for various categories of offence - as with the examples cited of assaults against police and cruelty to animals. As elsewhere women were much less likely to be implicated in criminal acts than men, but this data also suggests a relatively constant offending population whose risks of arrest varied only according to police priorities from time to time.

\section{CONCLUSION}

The study of violence in history has been dominated in recent years by issues in the history of policing and criminal justice. Establishing measures of the incidence of violence inevitably turns attention to the crucial data available through the modern institutions of criminal justice. The study of which this article is a part does not seek to displace such concern but rather to provide a level of scrutiny of the official data which has been absent from many studies. This scrutiny can be characterised in two ways: first, as one which looks at the data in a comparative context and, second, one which examines the relation between various indices of violence, including some which have been little regarded by other studies. Starting from the general conclusions of an earlier paper that the data in a comparative study of four countries exhibited a decline in inter-personal violence consistent with other international studies of the same period, this paper has focussed on the second level of scrutiny of the official data.

In doing so, we have seen how the strong evidence of decline in violence in the gross indices (homicide, assault) is modulated by a more detailed inspection of different kinds of policed offences. Notably such inspection has illustrated the value of 
examining categories such as sexual offences, domestic violence and assaults on children, and cruelty to animals. The policing data for such categories suggests interesting counterpoints to the overall picture of decline in the total record of offences of inter-personal violence. If we add to this data some measures of violence against the self, and asylum committals, the meanings of a 'decline in violence' are yet further complicated.

Further research in this project will be concerned to multiply the sources of data beyond official statistics. It will also be focussed on the appraisal of various explanations which might be (and have been) used in assessing the reasons for a long term decline in violence in western societies - administrative changes (policing and official statistics), biosocial (nutrition and so on), and cultural/governmental (including changing norms of social behaviour and governance of the self $)^{28}$. Having spent some time in this article on unpicking the tapestry of policing evidence it might be worth concluding on a note which focuses on the role of policing in the general decline in incidence of violence during this era.

Policing (through the activities of public or state police) was a mode of governing which combined a capacity for general surveillance with a high level of discretion in responding to local conditions. Such conditions might include political pressures from official government and from pressure groups and the media, as much in the nineteenth century as today. Given the general decline in recorded violence (evidently confirmed by the decline in homicide as a cause of death, with its implication of a declining propensity for violence) the Irish policing data on rape, aggravated assault and cruelty to animals was arguably a response to expectations or pressures that sought to bring these additional categories of violent acts to account. Where this policing priority was most effective in terms of increasing prosecutions (cruelty to animals notably, but aggravated assault as well for some part of this period) was in areas which were most likely to be subject public visibility and reporting - rape and attempts being a category most difficult to prosecute in the context of independent public witnesses. Such observations might serve as hypotheses for further investigation in the next stages of this study. They also presume a positive agency for police and policing as a crucial element in the later nineteenth century decline of inter-personal violence, another hypothesis for continuing investigation.

\section{REFERENCES}

Anderson, O., Suicide in Victorian and Edwardian England, Oxford, Clarendon Press, 1987. Bridgeman, I., Policing Rural Ireland, PhD thesis, The Open University, 1993.

Clark, S., and Donnelly, J. (eds.), Irish Peasants: Violence and Political Unrest, 1780-1914, Manchester, Manchester University Press, 1983.

Conley, C.A., The Unwritten Law, Oxford, Oxford University Press, 1991.

Conley, C.A., No pedestals: women and violence in nineteenth-century Ireland, Journal of Social History, 1995, 28, 4, p.801-818. 
Dawson, W.R., The Presidential Address on the Relation between the Geographical Distribution of Insanity and that of Certain Social and other Conditions in Ireland, The Journal of Mental Science, 1911, LVII, 239, (n.s. 203), p.571-597.

Finnane, M., Insanity and the Insane in post-Famine Ireland, 1981.

Finnane, M., Stevenson S., The decline of inter-personal violence 1860-1930: a cross-cultural comparison in four common-law systems, Social History Society of the UK Conference, Luton, January 1994.

Finnane, M., Irish crime without the outrage, in Osborough N. and Vaughan W., (eds.), The Administration of Criminal Justice in Nineteenth Century Ireland, Irish Legal History Society (forthcoming).

Fitzpatrick, D., Class, Family and Rural Unrest in Nineteenth Century Ireland, in Drudy, P.J., (ed.), Ireland: Land Politics and People, Cambridge, 1982.

Fitzpatrick, D., Unrest in rural Ireland, Irish Economic and Social History, 1985, XII, p.98105.

Gatrell, V.A.C., The Decline of Theft and Violence in Victorian and Edwardian England, in Gatrell, V.A.C., Lenman, B., Parker, G., (eds.), Crime and the Law. The Social History of Crime in Western Europe since 1500. London: Europa Publications, 1980, Ch.IX.

Gatrell, V.A.C., The Policeman State, in Thompson F. M. L., (ed.) The Cambridge Social History of Britain, 1750-1950, III, Cambridge University Press: 1991.

Griffin, B., The Irish police, 1836-1914: A social history, $\mathrm{PhD}$ thesis, Loyola University of Chicago, 1991.

Gurr, T. R., On the history of violent crime in Europe and America, in Gurr T. R., (ed.) Violence in America: Historical and Comparative Perspectives, Beverly Hills, Sage, 1979.

Johnson, E.A., Urbanization and Crime: Germany 1871-1914, Cambridge, Cambridge University Press, 1995.

Joyce, J., Dubliners, in Levin H., (ed.), The Essential James Joyce, Harmondsworth, Penguin, 1963, p. 374-5.

Lane, R., Violent Death in the City: Suicide, Accident and Murder in Nineteenth Century Philadelphia, Cambridge, Mass., Harvard University Press, 1979.

Lee, J., Ireland 1912-1985, Cambridge, Cambridge University Press, 1989.

Lowe, W., Malcolm, E., The domestication of the Royal Irish Constabulary, 1836-1922, Irish Economic and Social Review, 1992, XIX, p. $27-48$.

Maddox, B., Nora: a biography of Nora Joyce, London, Minerva, 1988.

Monkkonen, E., New York City homicides: a research note, Social Science History, 1994, 19, 2, p. 201-203.

Rose, R., Governing without Consensus: an Irish Perspective, Boston, Beacon Press, 1971.

Stevenson, S., An international decline of violence 1860-1930: if there was one, did it come from a new masculinity?, SSHA Conference, Atlanta, Georgia, 14 October 1994.

Townshend, C., Political Violence in Ireland, Oxford, Clarendon Press, 1983.

Vaughan, E.E., Landlords and Tenants in Mid-Victorian Ireland, Oxford, Clarendon Press, 1994,

Walsh, D., A Century of Suicide in Ireland, Journal of the Irish Medical Association, 1976, 69, 6 (March 27) p. 144-151. 